\title{
Management of soilborne diseases of beetroot in Australia: a review
}

\author{
H. L. Martin \\ Department of Primary Industries, Queensland Horticulture Institute, LMB 7, MS 437 Warrego Highway, \\ Gatton, Qld 4343, Australia; e-mail: Heidi.Martin@dpi.qld.gov.au
}

\begin{abstract}
Soilborne fungal diseases threaten the viability of the Australian processing beetroot industry. Globally, Pythium spp., Aphanomyces cochlioides and Rhizoctonia solani are the predominant soilborne fungal pathogens responsible for a root rot complex in beet crops. In Australia, the disease problems have been exacerbated in recent years because crops are now grown virtually year round, and under environmental conditions favourable to infection. This has lead to increased inoculum levels in soils sown to beetroot. Moreover, nowhere in the world does there seem to be a single strategy that is completely efficacious in controlling these pathogens, so an effective management strategy will almost certainly involve a combination of tactics. The most likely combination seems to involve fungicide seed treatments, rotations of gramineous or biofumigant crops and the use of disease-resistant varieties of beet. The first of these, fungicidal seed dressings, are a cost-effective means of reducing pathogen inoculum and protecting young beets from infection. Hymexazol may be particularly useful in the Australian system, since it is active against both Pythium and Aphanomyces. To combat Rhizoctonia, it should be applied in combination with either pencycuron or toclophos methyl. Second, rotations of gramineous crops, such as maize or oats, or biofumigant brassica crops, such as white mustard, brussel sprouts or cabbage should also reduce the build-up of inoculum and offers a tactic to relieve the problem in the longer term. Third, alternative beetroot cultivars with resistance to Rhizoctonia have now been developed in USA breeding programs and should be considered by the Australian industry. Resistant varieties are potentially very useful since they offer a long-term approach to disease management that can be easily incorporated into existing production systems. Fourth, the alteration of sowing dates to avoid periods of high disease risk (e.g. confining sowing to the cooler, drier months) needs to be seriously considered by the Australian industry if it is committed to disease management. There is also evidence to suggest that seed priming may warrant consideration as a tool to use in combination with fungicide dressings to reduce disease in young plants. Biological seed treatments and soil fumigation appear to be tactics of limited value to the Australian beet industry.
\end{abstract}

Additional keywords: seed treatments, crop rotations, resistant varieties, Pythium, Aphanomyces, Rhizoctonia.

\section{Introduction}

Soilborne fungal diseases are killing the Australian beetroot industry. Infections of young plants reduce crop stands, and later infections attack developing beets, reducing quality and increasing processing costs. In recent years, increasing demands from processors for raw product has resulted in an extension of the growing season into periods of high disease risk, which has further exacerbated the disease problems. Currently, the Australian beetroot industry is at a crossroad. It can either continue on its present path and risk failing completely, or it can change its current production practices to better manage its soilborne diseases. To change, members of the industry must have a clear understanding of the causes of these diseases and the management possibilities that are available and which are likely to reduce disease severity.

Three genera of fungi (Pythium, Rhizoctonia and Aphanomyces) are primarily responsible for root rot disease in beetroot. In Australia all 3 genera have been found to be associated with this problem at various times (Hutton and O'Brien 1986; O'Brien et al. 1998); however, research results being prepared for publication (H. L. Martin unpublished data) indicate that Pythium and Rhizoctonia are currently the most important.

Numerous approaches to controlling this disease have been explored in various parts of the world, including fungicides (Asher and Payne 1989; Heijbroek and Huijbregts 1995), biological control agents (Lewis and Papavizas 1987a), seed priming (Osburn and Schroth 1989), crop rotations (Rush and Winter 1990), soil fumigation (Harveson and Rush 1994) and resistant plant varieties (Goldman 1996). However, most of the information available on soilborne disease management in beet comes from overseas studies on sugarbeet and none of this work has been validated on beet crops in Australia. Nevertheless, given the close relationship between sugarbeet and beetroot it would 
be surprising if many conclusions from international sugarbeet research could not be validly translated to the Australian context, and so they will be taken into consideration in this review when establishing a disease management strategy for the Australian beetroot industry.

Since a complex of fungal pathogens causes root rot in beets, we might expect that no single tactic would prove effective for complete, long-term disease control and it will be shown in this review that a combination of approaches may be required as a management strategy for the Australian industry. The most promising strategy seems to be to combine: beet varieties with resistance to Rhizoctonia; a fungicide seed dressing combination of hymexazol and pencycuron or tolclophos methyl; rotations of gramineous crops and/or biofumigant crops; and confinement of sowing to the cooler, drier months when there is lower risk of disease infection. Seed priming also warrants consideration. Together, these tactics seem likely to hold the key to the survival of the Australian beetroot industry.

\section{Soilborne diseases of beetroot: cause and effect Pathogens}

In Australia, 3 genera of soilborne fungi, Pythium Pringsh. spp., Aphanomyces cochlioides Drechs. and Rhizoctonia solani Kühn, have been reported as the predominant soilborne pathogens involved in a beetroot root rot complex since the 1980s (Hutton and O'Brien 1986; Tesoriero 1993). The severity of the disease in this industry has increased significantly since this time, and my recent work, which is yet to be published, indicates that Pythium spp. and Rhizoctonia are now the most important species. The same 3 genera have also been recognised for many years as pathogens of beet in other parts of the world (Mumford 1968; Vestbury et al. 1982; Whitney and Duffus 1986; Asher and Payne 1989). Acute and chronic phases of this disease complex have been differentiated (Coons et al. 1946). In the acute stage, young plants are killed during germination or 1-2 weeks after emergence from the soil. The seedlings that survive the initial attack often show disease symptoms on their main or lateral roots that are characteristic of the primary pathogen involved. The symptoms in the later stages of growth are manifestations of the chronic phase.

Pythium. Pathogenic Pythium species are important in both the acute and chronic phases of disease on beets, and cause both pre- and post-emergence damping-off problems in beet seedlings as well as root rots in older plants. Globally, 12 species of Pythium [including P. ultimum (Trow), P. aphanidermatum (Edson) Fitzp., P. irregulare Buisman, $P$. debaryanum R. Hesse, P. salpingophorum Drechsler, P. dissotocum Drechsler, $P$. deliense Meurs, P. acanthicum Drechsler and P. myriotylum Drechsler.] have been reported to attack beets (Kuznia and Windels 1993). Pythium ultimum and $P$. aphanidermatum are generally considered to be the most important pathogenic species. In Australia, a colleague and I have identified 3 species (P. aphanidermatum, $P$. ultimum and $P$. dissotocum) that contribute to the beetroot disease complex to date. Serious losses due to Pythium have been reported in the USA (Brantner and Windels 1998; Bretzel et al. 1988; Hancock 1977; Johnson and Halloin 2000; Kuznia and Windels 1993; Mumford 1968; Ruppel et al. 1988), Finland (Vestburg et al. 1982), England (Asher and Payne 1989), Northern France and Yugoslavia (Asher and Payne 1989).

In the young seedling, Pythium spreads quickly from the roots to the stem, which becomes soft and watery before the seedling collapses. Root infection of mature plants causes feeder root sections to die and also, may produce excessive root hairiness (O'Brien 1988). Aboveground symptoms include wilting, yellowing and death of lower leaves (Whitney and Duffus 1986).

Aphanomyces cochlioides. Aphanomyces cochlioides produces an acute seedling blight and a chronic root rot of beets. This fungus causes only minimal pre-emergence damping-off, but infection immediately after emergence produces a red discolouration of the cotyledons and young leaves. The fungus invades the hypocotyls of young seedlings, causing a brown discolouration that may extend up to the base of the cotyledons. The hypocotyls are weakened by this attack and the seedlings may collapse and die. Those that do survive are usually stunted. Below ground, the taproot also becomes withered, blackened and 'wiry' in appearance. In a survey of 27 farms in the Lockyer Valley, south-east Queensland, A. cochlioides was the pathogen most commonly isolated from diseased beetroot seedlings during 1979-81 (Hutton and O'Brien 1986). In parts of the USA, this pathogen is also considered the primary cause of seedling disease in sugar beet (Rush and Vaughn 1993).

Mature plants may also be affected and show yellowing and wilting of foliage and unthrifty top growth, as well as black lesions on roots and large, depressed, black lesions on the beets themselves (Hutton and O'Brien 1986; Whitney and Duffus 1986). Outside Australia, abundant lateral root development has been reported as a symptom of this disease, but, in Australia, this symptom has more commonly been associated with infection by Pythium spp. (O'Brien 1988). The chronic phase of the disease has been reported in the USA, Canada, England, Germany and Japan as well as Australia.

Rhizoctonia. Rhizoctonia solani causes pre- and post-emergence seedling death as well as root, foliar and crown rot of beet plants. The fungus is found in agricultural soils throughout the world and it attacks many crop species, including beans, cabbage, lettuce, peas and potatoes (Abawi et al. 1986). This pathogen is the most common and serious root disease of beet in the USA and it has been reported as an important disease in most other areas of the world where beet crops are grown (Whitney and Duffus 1986). Rhizoctonia spp. are classified by means of hyphal anastomosis reactions between isolates. In sugar beet, anastomosis group (AG) 2-2 is the major $\mathrm{AG}$ world-wide, causing crown and root rot 
(Herr 1991), whereas AG-4 is more commonly involved in damping-off (Kiewnick et al. 2001). A study of 107 Rhizoctonia isolates collected from diseased beetroots in New York State revealed that other $R$. solani anastomosis groups and other Rhizoctonia species may also be pathogenic to beetroot. Ninety-eight of the isolates were multinucleate, with diagnostic characteristics of $R$. solani, whereas the remaining 9 , originating from root tissues, were binucleate Rhizoctonia species. About $88 \%$ of the $R$. solani isolates belonged to AG 2-2 and the remainder were from AG-5, AG-4, or AG 2-1. Isolates from AG-5 and AG-4 were low to moderately virulent to leaves and highly virulent to roots. The binucleate isolates were weakly virulent to leaves and roots (Olaya and Abawi 1994a).

As a seedling pathogen, $R$. solani causes some pre-emergence death but it inflicts most of its damage on seedlings that have already emerged. Infection is initiated below ground and extends up the hypocotyl, producing a dark pinched area near ground level (O’Brien et al. 1998). The seedling often collapses at this point.

Later in the growing season, Rhizoctonia may cause a crown rot on maturing beets. Initial diagnostic symptoms include brown to black cankers on petioles and crown tissues. Rotting proceeds towards the crown and roots of the plant and is accompanied by wilting and yellowing of the leaves (Abawi and Ludwig 2000; Scholten et al. 2001). Irregular, depressed, dark lesions may develop on the surfaces of the beets. Fungal growth is often visible on the surfaces of these lesions (Whitney and Duffus 1986). In New York State, the teleomorph of Rhizoctonia solani, Thanatephorus cucumeris (A.B. Frank) has been observed under commercial field conditions. The sexual state produces airborne basidiospores that are easily carried by wind and splashing rain to neighbouring plants, which may be an important factor in the spread of the disease within beet crops (Olaya and Abawi 1994b). The primary source of inoculum for the development of foliar and crown rot symptoms in New York, however, is considered to be infested soil thrown onto petioles and crowns of plants during cultivation (Olaya and Abawi 1994b).

\section{Environment}

Pythium spp. are adapted to survive and proliferate in wet soils, particularly when moist conditions prevail for prolonged periods of time. The fungus spreads through the soil via motile zoospores. Thick-walled oospores enable long-term survival of the pathogen. In wet soils, seed treated with fungicides may not be able to withstand high disease pressure, resulting in poor stand establishment. Conditions that delay seedling emergence, such as compacted soil or excessively deep planting, or if seed is of low vigor, increase the time of exposure of germinating seed to possible infection by Pythium.
Relationships between soil temperature, soil moisture and organic matter are critical in the development of Pythium epidemics in the field (Hancock 1977). Species-specific temperature requirements have been demonstrated in several studies (Bretzel et al. 1988; Hancock 1977; Kuznia and Windels 1993; Raftoyannis and Dick 2002). For example, in a field survey in North Dakota and Minnesota, Kuznia and Windels (1993) found that $P$. aphanidermatum caused more seed rot and damping-off when soil temperatures increased from 14 to $31^{\circ} \mathrm{C}$, whereas the reverse relationship was observed for P. ultimum. Similarly, high soil temperatures $\left(30-37^{\circ} \mathrm{C}\right.$ during July and August) were identified as contributing to the uniformly low levels of P. ultimum in field soils of the San Joaquin Valley in California (Hancock 1977), whereas the onset of disease caused by $P$. aphanidermatum in central Arizona coincided with the occurrence of temperatures of $27^{\circ} \mathrm{C}$ or more for at least $12 \mathrm{~h}$ per day, provided adequate soil moisture was available (Bretzel et al. 1988). In view of the fact that there are several different pathogenic species of Pythium on beetroot in Australia, species-specific temperature requirements may be an important consideration in a disease management strategy. In particular, there may be an opportunity to manipulate planting dates depending on which pathogens are present at particular sites. For example, sowing beets into soils known to contain species favoured by relatively high temperatures should be avoided during the summer months.

The importance of soil moisture for the onset of epidemics was demonstrated in California. Field populations of $P$. ultimum increased substantially at water potentials between -0.3 and -8 bars, whereas no population increases occurred under drier conditions. In this instance, the disease increased rapidly in the autumn months (when temperatures were favourable) when moisture was available after irrigation (Hancock 1977). In a similar study in Arizona, the infection rate of mature sugar beet by $P$. aphidermatum fell dramatically when the irrigation was cut off, even in the presence of soil temperatures conducive to infection (Bretzel et al. 1988).

Aphanomyces cochlioides is similar to Pythium in its environmental requirements. High soil temperatures $\left(20-28^{\circ} \mathrm{C}\right)$ and wet conditions favour infection. Plant infections are initiated by swimming zoospores that are released during wet weather or following irrigation. In a similar way to Pythium, this fungus also produces thick-walled highly resistant spores that allow long-term survival of the pathogen, even when the soil dries out. In England, the disease has been reported to occur most frequently in acid soils (Byford 1975). Increasing pressure on Queensland producers to sow beet crops during the summer months under warm, wet conditions, increases the risk of root rots by Aphanomyces and may explain the prevalence of this fungus in previous surveys of the Lockyer Valley (Hutton and O’Brien 1986; O'Brien et al. 1998). 
Rhizoctonia, in the form of hyphae, survives in soil in colonised host tissues. Survival in the soil as sclerotia has also been reported in Japan (Hyakumachi and Ui 1982) and in New York State (Abawi et al. 1986). Under warm soil temperatures $\left(25-33^{\circ} \mathrm{C}\right)$, the fungus grows through the soil and infects the plant through its leaves, petioles, crown and roots. The disease occurs in most soil types, but is more severe in moist soils (Rush and Winter 1990; Kiewnick et al. 2001), especially in low areas where water collects (Whitney and Duffus 1986). Rain, irrigation water or rain splash play an important role in the distribution and spread of sclerotia, infected plant debris or basidospores of R. solani (Baker and Martinson 1970). Crown rot of beets is severe when long periods of wet conditions prevail, since beet petioles and crowns retain moisture, thus providing favourable conditions for disease development (Olaya and Abawi 1994b). Since organic matter plays an important role in harboring the pathogen between crops, sowing too soon after ploughing in a cover crop may lead to high levels of infection if the cover crop debris is not adequately broken-down before the new crop is planted. This factor was identified as an important consideration for beetroot producers in the Lockyer Valley of south-east Queensland (O'Brien et al. 1998). I believe it has become even more important in Australia since, because the number of beetroot farmers has declined and the beet production season has been necessarily extended to meet processing contract requirements. Under this current Australian system, planting schedules are tight and there is often insufficient time for crop residues to break down sufficiently so as not to pose a threat of disease carry-over to a subsequent crop.

In summary, all 3 genera of beet fungal pathogens (Pythium, Aphanomyces and Rhizoctonia) are favoured by wet soils but temperatures conducive to infection do vary particularly among Pythium species. Species-specific temperature requirements offer the possibility of manipulating sowing times at specific sites, depending on which pathogens are present, for example, sowing into soil during the winter months, if the soil is known to contain a species favoured by warmer temperatures. Consideration of the temperatures required for infection by each pathogenic species may be an important tactic in the development of a disease management strategy in Australia, since at least 3 species of Pythium are known to cause disease. For Rhizoctonia management, pathogen carry-over on old crop residues is particularly important, and the implication of previous crops on disease severity needs to be considered seriously by Australian producers, because of the long growing season and short turnaround between harvest and replant on sites grown to beetroot.

\section{Control of the soilborne pathogens of beet Pre-planting treatment options}

Seed fungicide treatments. The 3 major soilborne fungal pathogens that cause root rot in beets are all detrimental to the early crop growth stages if conditions are favourable. For this reason, control or reduction of the diseases through application of fungicides to the beet seed seems to be a plausible control method and it is the one that has been the focus of the most research effort. In the case of beetroot, however, if all 3 fungi associated with disease are present in the field at the one time, fungicide control options become complicated, since fungicides vary in their activity against different taxonomic groups of fungi. A single chemical with broad-spectrum activity against all the soilborne fungal pathogens of beetroot is currently unavailable. Knowledge of the identity of the pathogens involved in each instance is therefore important. A combination of 2 or more fungicides may be necessary to protect against the spectrum of anticipated pathogens. As an additional complication, the simultaneous application of several different fungicides to the seed increases the likelihood of toxicity to the young germinating seedling.

Since the mid-1970s, trial work in several countries has investigated the best fungicide(s) to use in the seed pellet to control these pathogens. Until 1981, most countries were relying on thiram to give control of both seed and soilborne diseases. Thiram, a protectant fungicide, is relatively effective under low disease pressure and is one of the least expensive fungicides available. Thiram is applied as a standard seed dressing to beetroot seed in Australia; however, because of its mode of action, it only creates a localised zone of protection around the germinating seed. Thiram has also been used in England to control deep-seated seed infection of Phoma betae (Frank) in sugar beet and beetroot seed. In this case, the fungicide $(0.2 \%)$ is applied as a prolonged (24 h) steep (Maude et al. 1969). The steeping process not only provides good control of the pathogen, but also results in more rapid seedling emergence (Durrant et al. 1988). Instability of thiram in pelleted sugar beet seed has, however, been reported (Huijbregts et al. 1995).

Systemic fungicides that can be absorbed during early seedling growth, should offer more extensive protection than thiram, particularly when infection takes place not through the root systems and the seed, but directly into the hypocotyl at some distance from the pellet, as is often the case with Aphanomyces infection. A range of systemic actives has been examined for control of Pythium and Aphanomyces, including captafol, hymexazol, metalaxyl and propamocarb (Asher and Payne 1989).

Metalaxyl has shown promise as a beet seed dressing for control of Pythium spp. both in Australia (O'Brien et al. 1998) and overseas (Abdalla and El-Gizawy 2000; Brantner and Windels 1998; Crosier et al. 1986) and it is now registered in Australia, along with thiram, for this purpose. Since 1992, all sugarbeet seed sold to producers in the Red River Valley of Minnesota and North Dakota and in west-central Minnesota has been treated with metalaxyl (Brantner and Windels 1998). Emergence of seedlings in this 
region is still often reduced by Pythium infections; however, leading researchers to suggest and test the theory that variation in sensitivity of Pythium isolates to metalaxyl may be partly responsible (Brantner and Windels 1998). They concluded that the continued use of this fungicide as a seed treatment poses only limited risk for the development of metalaxyl-resistant isolates. This conclusion was based on the consideration that only a small amount of fungicide is applied to the seed; it persists in the soil for only a short time and only a small proportion of the Pythium population in the soil is exposed to the treatment. A more recent study further supports this view. The presence of metalaxyl-resistance was examined by screening pathogenic Pythium isolates collected from diseased sugar beets in Michigan. Pythium ultimum isolates exhibited negligible resistance to metalaxyl in this case (Johnson and Halloin 2001). It seems reasonable to assume, however, that if soil applications of metalaxyl are used in addition to seed treatments, the risk of selecting insensitive strains of the pathogen will increase and possibly reduce disease control (Brantner and Windels 1998).

Metalaxyl, although effective for Pythium control, is not active against either Aphanomyces or Rhizoctonia. For this reason, there has recently been a lot of interest in hymexazol as a seed treatment, since it was active against both Pythium and Aphanomyces in trials in several countries (Byford and Payne 1983; Heijbroek and Huijbregts 1995; Payne and Williams 1990). In particular, P. aphanidermatum was identified as being highly sensitive to hymexazol (Nakanishi and Sisler 1983).

Rates of application of hymexazol vary between countries. In England and Finland a rate of $10 \mathrm{~g}$ a.i. $/ \mathrm{kg}$ of seed was found to be optimal in field trials (Byford and Payne 1983; Vestburg et al.1982). Since 1983, sugar beet seed treated with hymexazol at $10 \mathrm{~g}$ a.i./kg has been commercially available in England. Elsewhere in Europe, the rates of hymexazol used for Aphanomyces and Pythium control vary widely, probably reflecting the different disease situations in the growing regions (Asher and Payne 1989). In France, seed treated with 28 or $42 \mathrm{~g}$ a.i./unit is available to growers in regions with serious problems. In the Netherlands, early in the season, quantities of about $10 \mathrm{~g}$ a.i./unit provide sufficient control, whereas by the end of the season rates of greater than $20 \mathrm{~g}$ a.i./unit are necessary (Heijbroek and Huijbregts 1995). Similarly, in England under conditions of severe disease pressure, rates of $21 \mathrm{~g}$ a.i. $/ \mathrm{kg}$ are required for maximum disease control (Payne and Williams 1990).

Evidence from a large number of trials indicates that hymexazol rates in excess of $20 \mathrm{~g}$ a.i. $/ \mathrm{kg}$ can slow seedling emergence (Asher and Payne 1989). Consequently, if high rates are to be applied as single applications, as in England, any potential benefits must be balanced with the possible adverse effect of the chemical on seedling emergence. To combat this, a good compromise may be to apply hymexazol to seed using a pelleting system in order to keep the active away from the seed. Additionally, only seed with high germination and strong vigor should be treated with this fungicide (Anfinrud 1999). The alternative strategy, as adopted in France, is to provide seed treated with different rates of product for use where the disease is anticipated. However, this strategy may create logistic difficulties and would only be effective if sites prone to the disease, and the environmental conditions favourable for its development each year, can be predicted with reasonable accuracy (Asher and Payne 1989). Nevertheless, it may be a rational proposition for Australian beetroot production systems, since beetroot is primarily produced in 1 district in Australia. Consequently, environmental variability between sites is likely to be relatively small.

Deviations between the actual rate of application and the target rate of application may also occur and have been noted when hymexazol is incorporated in pelleted seed (Heijbroek and Huijbregts 1995). These deviations have been attributed to the unstable nature of hymexazol and its tendency to degrade in the pellet (Huijbregts et al. 1995). The composition of the pelleting mass and the addition of carbamate insecticides along with hymexazol may also influence the degradation. Heijbroek and Huijbregts (1995) suggested that an overdose of hymexazol should be applied to pelleted seed to compensate for the degradation and mentioned the importance of sowing the seed soon after pelleting to limit the extent of chemical breakdown.

Several fungicides are reportedly effective for control of Rhizoctonia solani when applied as seed dressings. In the western United States, most beet seed is treated with pentachloronitrobenzene (PCNB) to protect against Rhizoctonia infection (Whitney and Duffus 1986). Tolclophos methyl has also been found to be effective against $R$. solani both in Australia (O'Brien et al. 1998) and elsewhere. In a glasshouse assessment of fungicidal seed dressings, tolclophos methyl gave complete protection against Rhizoctonia infection when it was applied as a slurry (2 g seed $/ \mathrm{kg}$ ) to monogerm beetroot seed (O'Brien et al. 1998).

Pencycuron is another chemical with specific activity against $R$. solani (Yamada 1986). In experiments, dry seed dressings of pencycuron at $0.5-1.5 \mathrm{~g}$ a.i. $/ \mathrm{kg}$ seed were promising, particularly when combined with Euparen (Yamada 1986).

Seed priming treatments. Beetroot seeds are slow and often asynchronous in their germination. These characteristics interfere with the early establishment of a uniform, vigorous stand of seedlings, particularly in cold, wet soil (Khan et al. 1983). Seed priming typically increases the rate, uniformity, and percentage of seed germination, resulting in improvement of stand and often of yield. Seed priming is a pre-sowing treatment in which seed germination processes are initiated and stopped before radicle 
emergence. It is usually of greatest benefit under environmental conditions that are suboptimal for seed germination and emergence, such as cool, wet conditions (Osburn and Schroth 1988). Various priming techniques have been developed including osmopriming, in which seeds are allowed to imbibe in an aerated osmotic solution such as polyethylene glycol (PEG) or a solution containing inorganic salts. The osmotic potential of the solution regulates the amount of water uptake by the seeds, thus enabling the completion of the early phases of germination under controlled conditions. The duration of the priming treatment may range from less than $24 \mathrm{~h}$ (Guedes and Cantliffe 1980) to several weeks (Khan et al. 1980). Several American studies have indicated that osmopriming beetroot seed in PEG improves the emergence rate, the final stand and total yield of beetroot crops (Khan et al. 1983; Khan and Taylor 1986). Solid matrix priming is a more recent development and uses a solid carrier to regulate water availability to seeds. This type of priming was as good as or better than osmopriming at speeding seedling germination in several studies (Harman et al. 1988; Rush 1991).

In addition to improvements in germination rate and emergence, osmopriming with PEG or $\mathrm{NaCl}$ (Abdalla and El-Gizawy 2000; Osburn and Schroth 1988; Osburn and Schroth 1989; Rush 1992; Taylor et al. 1985) and solid matrix priming with water and hydrous silicate clay (Rush 1991; Rush and Vaughn 1993) have both been reported to significantly reduce pre-emergence damping-off in beets caused by Pythium spp. Disease control levels comparable with or better than achieved by treating the seed with metalaxyl have been reported, and when combined, the osmoprimed and fungicide seed treatments resulted in even greater disease reductions (Osburn and Schroth 1989). Pythium spores germinate in response to nutrients diffusing from imbibing seeds (Osburn and Schroth 1988). Priming treatments leach soluble exudates from the seed and as a consequence, seed colonisation by the pathogen is reduced when the seed is re-wetted. In addition, bacteria, present on the seed coat, multiply in the osmotic solution during seed treatment and may help to prevent colonisation of the seed by Pythium spp. (Taylor et al. 1985).

Studies on the effect of seed priming on post-emergence damping-off caused by Aphanomyces cochlioides, indicate that seed priming treatments are ineffective for control of this pathogen (Rush 1992; Rush and Vaughn 1993). In comparison, osmopriming has been shown to reduce pre-emergence damping-off caused by Rhizoctonia solani (Osburn and Scroth 1989). This pathogen is not controlled by metalaxyl and therefore planting osmoprimed seed in soils infested with $R$. solani may offer additional protection against Rhizoctonia when the standard fungicide seed dressings are inadequate.

Although the efficacy of osmopriming beet seed has been demonstrated in the numerous studies discussed above, several technical difficulties have been encountered with priming methods. Osmotic solutions require continuous aeration and a large volume of priming solution is required per quantity of seed. As well as this, the use of high concentrations of PEG in solution has low oxygen solubility and diffusivity (Mexal et al. 1975). These aspects complicate the priming process and will need to be overcome if priming of beetroot seed is to become a commercial reality.

Biological seed treatments. Most of the available literature on control of soilborne beet pathogens with biological treatments relates to the biological control of P. ultimum. Only very limited consideration has been given to the possibility of biological control of other species of Pythium or either A. cochlioides or R. solani in beet crops. As for fungicide seed treatments, the discovery of a single broadspectrum biological control agent active against all 3 major soilborne pathogens of beets is unlikely. In addition, poor colonisation of the rhizosphere by the biological control agent is a major constraint of seed treatment biological control (Walker et al. 2002).

Pythium ultimum was considered by Osburn et al. (1989) to be an ideal candidate for biological control because the susceptible period for the host is relatively short for this pathogen, negating the need for high populations of the control organism for extended periods of time. They identified 2 bacterial strains: Pseudomonas fluorescensputida (R20) and P. putida (ML5), which, when inoculated onto sugar beet seed, markedly reduced colonisation by Pythium ultimum and gave comparable control to fungicides (metalaxyl or fenaminosulf) in suppressing damping-off in greenhouse experiments. Similarly, antagonistic Pseudomonas spp. achieved satisfactory control of P. ultimum when applied to sugar beet seeds in a Greek study (Georgakopoulos et al. 2002). A strain of Pseudomonas fluorescens also demonstrated a strong inhibitory effect on the development of both mycelial biomass and sclerotial formation by $R$. solani in sugar beet seedlings (Thrane et al. 2001). More common in the literature, however, are reports of poor control of beet pathogens with biological agents or control levels inferior to those achieved with fungicides, particularly under high disease pressure (Whipps et al. 1993; Williams and Asher 1996). Maintaining viability of microorganisms in the seed pellet is a significant obstacle to their efficacy. The type and amount of inoculum applied, the method and timing of application and the age of the inoculum may also reduce the efficacy of biological control agents. For example, Trichoderma hamatum Rifai as a seed dressing, has shown promise as a biological control agent for $R$. solani in beet (Lewis and Papavizas 1987a, 1987b), reducing the survival of the pathogen by about $90 \%$ after 1 week. However, if the control agent was added to soil before the presence of the pathogen, the pathogen survival was not reduced, illustrating the critical importance of correct timing of application for the biological control agent. 
Also, the age of the inoculum greatly affected the ability of T. hamatum to limit survival and growth of the pathogen in soil. Young, actively growing inoculum was effective whereas inoculum consisting mainly of resting spores was not (Lewis and Papavizas 1987a). An alginate pellet formulation of $T$. hamatum was developed to assist with application, however the storage of the pellets for more than 6 weeks at 5 or $25^{\circ} \mathrm{C}$ also reduced their effectiveness against R. solani (Lewis and Papavizas 1987b).

In consideration of the literature, at present, seed applications of biological control agents for soilborne beet pathogens are unlikely to represent a feasible commercial proposition since (i) the control levels achieved are generally inferior to those currently provided by fungicides, and (ii) environmental variables markedly influence the efficacy of biological treatments. Of particular importance to Australian beet producers is the tendency of biological agents to perform best in soils with a relatively high organic matter content. Australian beet soils are typically low in organic matter and biological agents endemic to Australian soils are yet to be developed commercially. Commercial products currently available are therefore unlikely to survive in Australian soils.

For Australian beetroot producers, fungicides combined with priming treatments offer the best prospect as seed treatments for control of early disease infection. Priming seed before fungicide application increases the rate of seedling emergence. Rapid plant establishment following priming may indirectly help reduce pre-emergence losses due to Pythium and Rhizoctonia, because the time before emergence is reduced and hence there is less time available in which the germinating seedling is susceptible to infection. The Australian industry should also consider hymexazol as a replacement for the standard metalaxyl and thiram dressing combination, since it is active against both Pythium and Aphanomyces. There may be scope to manipulate the rate of hymexazol applied to the seed, depending on the time of year that the seed is planted. For example, higher rates should be used at the extremities of the growing season when temperatures and rainfall are high. A fungicide specific against Rhizoctonia such as tolclophos-methyl or pencycuron should be applied along with the hymexazol to give broad-spectrum protection against all 3 fungal pathogens.

Fumigation. Globally, methyl bromide $\left(\mathrm{CH}_{3} \mathrm{Br}\right)$ has been the most widely used and effective fumigant for many years. This compound will be phased out of use by 2005 , under the Montreal Protocol, because it is an ozone-depleting chemical (Ohr et al. 1996). Assessment of potential replacements for methyl bromide has been the focus of considerable research effort.

Metham sodium is currently the only commercially available alternative to methyl bromide and it is widely used in Australia and overseas for control of a range of soilborne diseases in horticultural crops including Pythium spp.
(Roberts et al. 1988; Stephens et al. 1999; Yuen et al. 1991) and R. solani (Stephens et al. 1999; Wicks et al. 1996).

Unfortunately, metham sodium is prone to biodegradation (Matthiessen 1999). Biodegradation is a phenomenon whereby a pesticide is metabolised by soil microorganisms that are stimulated to dominate the soil microbial population by repeated applications of the chemical. This is particularly a problem with modern pesticides because they are not halogenated and are therefore more prone to breakdown via microbial activity (Matthiesen 1999).

Other potential fumigants have been trialed but as yet, remain uncommercial. The fumigant Telone II (1,3-dichloropropene) was evaluated for control of soilborne pathogens of sugar beet because of its cost efficiency and efficacy at low rates. Yields were significantly increased in fumigated plots in a field study (Harveson and Rush 1994). Methyl iodide has also been evaluated as a potential methyl bromide replacement and was found to be as effective or more effective than methyl bromide as a fumigant for control of soilborne fungi, including R. solani (Becker et al. 1998; Ohr et al. 1996). Unfortunately, the relative cost of methyl iodide compared with other fumigants was not discussed in these publications and would need to be investigated in any future consideration of this product. Benzaldehyde was also shown to reduce the viability of $R$. solani and reduce populations of $P$. aphanidermatum in a laboratory study (Wilson et al. 1999). This chemical is considered a desirable alternative to methyl bromide because it is inexpensive and its breakdown products $\left(\mathrm{CO}_{2}\right.$ and $\left.\mathrm{H}_{2} \mathrm{O}\right)$ are harmless to the environment.

In beet production, aside from efficacy constraints, many fumigants are also not economically feasible (Harveson and Rush 1994). It seems likely that a beneficial response to fumigation would need to be observed across several cropping cycles and/or to crops grown in rotation with beet for these economic constraints to be overcome. For Australian beetroot growers, it is likely to be economic constraints rather than efficacy constraints that prevent the widespread use of metham sodium as a fumigant. Anecdotal reports from Australian beetroot growers indicate that substantial disease control may be achieved with metham sodium, but due to tight margins between production costs and financial returns, a metham application would need to offer significant benefit to more than 1 crop cycle for it to be economically feasible.

Biofumigation. The problem of biodegradation of metham sodium and the relatively high cost of this chemical has prompted researchers to investigate other non-synthetic methods of fumigation. The term biofumigation has been coined and adopted to describe the concept of using Brassica plants to control soilborne pests and diseases in other crops (Matthiessen 1994).

The ability of Brassica amendments to reduce some fungal and nematode populations has been attributed to their 
production of gluconsinolates (Lewis and Papavizas 1971b). These compounds are released when Brassica plants are physically broken up and during the breakdown of Brassica residues in soil. Gluconsinolates are precursors of isothiocyanates and metham sodium is an isothiocyanate (Matthiessen 1994).

The effects of biofumigation on many soilborne pathogens have been reported in a range of cropping systems. For example, dried cabbage residue reduced soil populations of Fusarium oxysporum f.sp. conglutinans (Ramirez-Villapudua and Munnecke 1988), and superior growth of wheat following Brassica crops was attributed to suppression of soilborne fungal pathogens, including $R$. solani (Kirkegaard et al. 1996). Damping-off of sugar beet caused by $A$. cochlioides was reduced by soil amendments of eight Brassica species (mustard, brussel sprouts, kale, collards, cress, cabbage, turnip and kohlrabi), in a glasshouse study (Lewis and Papavizas 1971a). Similarly, Aphanomyces euteiches, the causative agent of root rot of pea, was suppressed by volatiles released during the breakdown of cabbage tissue in the laboratory (Lewis and Papavizas 1971b). Field experiments in which white mustard (Sinapis alba L.) significantly reduced root rot (A. euteiches) in pea plants grown the following year, further supported these early glasshouse experiments (Muehlchen et al. 1990).

Although there are numerous reports in the literature highlighting the benefits of biofumigation, several studies investigating biofumigation for control of soilborne Pythium diseases have not been promising (Kirkegaard et al. 1996; Stephens et al. 1999). Recently, Pythium spp. have been shown to be relatively insensitive to volatiles from mustard (Matthiessen and Kirkegaard 1996).

The degree of fungal suppression by Brassica crops depends on the type and concentration of gluconsinolates evolved, which in turn is influenced by the species, age, and type of Brassica tissue. Recently in Australia, more than 100 different Brassica spp. were assayed for glucosinolate production (Matthiesen and Kirkegaard 1996) and seed of the most promising types is now being commercially produced for use in biofumigation.

Crop rotations. Cropping beets at high frequency increases soilborne pathogen populations, resulting in yield losses. When beet is grown on the same ground more than once in 3 years, it generally does not reach its full yield potential (Schauffle and Winner 1979). For this reason, 3-5-year rotations out of beet is standard industry practice in beet cropping regions in the United States. (Herr 1987; Rush and Winter 1990).

Preceding beet crops with leguminous plants such as pea, field bean or red clover raised the inoculum density of Pythium in soil and kept the level of damping-off unchanged or slightly elevated, when compared with continuously cultivated sugar beet, in a Finnish glasshouse study. In comparison, gramineous plants had the opposite effect, increasing emergence and the numbers of healthy plants and decreasing the inoculum density of Pythium (Vestburg 1987).

Losses due to Aphanomyces are most severe when beets are grown immediately following lucerne (Deems and Young 1956; Mumford 1968; Schneider and Robertson 1975). Striking effects on disease incidence resulted from cropping soil thoroughly infested with $A$. cochlioides to lucerne, corn, oats and sugar beet in an Ohio field trial (Deems and Young 1956). Sugar beets maintained a $95-100 \%$ inoculum potential thoroughout the season. In contrast, cropping to corn and oats reduced disease. Corn was the most effective rotation in terms of Aphanomyces control, decreasing disease incidence to $10 \%$ after 3 months and maintaining disease at low levels. Oats decreased disease to $25 \%$ during the first 4 months, however disease levels increased markedly once the oats were 'ploughed down'. Lucerne did not decrease Aphanomyces incidence to levels below those in soils continuously cropped with sugar beet (Deems and Young 1956).

Crown rot caused by R. solani was also more severe where beets followed lucerne than where beets followed corn, soybeans or navybeans, in 5-year field rotations in Michigan (Schneider and Robertson 1975). Similarly, cotton, fallow and sunflower were superior to lucerne as rotations to precede beet in Rhizoctonia infested soil in Texas, USA (Rush and Winter 1990).

For Rhizoctonia management, tomato and potato are also poor crops to plant before beet. High $R$. solani populations developed saprophytically on tomato crop residues in an Ohio field trial, and although tomato is not considered to be a particularly good host for $R$. solani, its survival on the fruit and vines after harvest allowed it to persist until the following spring (Herr 1987). Two-year rotations between beet and potato also produced increased losses from Rhizoctonia in beet crops, because of the pathogen's ability to survive between crops on undecomposed potato debris (Schuster and Harris 1960).

The use of rotation crops that reduce or do not promote inoculum build-up in subsequent beetroot crops, is an option that must be embraced by the Australian beetroot industry as a longer-term soil health management opportunity. In particular, on the basis of the literature, gramineous crops such as corn or oats, or Brassica crops warrant investigation in this capacity. In the Lockyer Valley district, where most Australian beetroot is grown, there is a Brassica-free period imposed by the local Brassica industry for control of diamondback moth, from November through January. For this reason, Brassica rotations would only be a feasible option for the winter months in this district. However, since Brassica crops do have the potential for biofumigant activity, winter rotations with beetroot may offer significant long-term benefits and should be utilised if possible. 


\section{Post-planting treatment options}

Fungicides. The majority of research on fungicide treatments for soilborne pathogens of beet has been directed towards pre-planting seed applications. This concentration of research effort is understandable since seed applications represent one of the best options for combating early infections. Beet pathogens do, however, cause losses and quality reductions of mature plants under appropriate environmental conditions, and hence fungicide applications following seedling emergence may also offer some benefit.

In Australia, no systemic fungicides are registered for use on beetroot as post-emergence treatments. In the USA, metalaxyl is available for use as a supplemental in-furrow treatment applied at planting, however it is not commonly applied because early Pythium spp. infections are normally adequately controlled by seed dressings (Brantner and Windels 1998).

A range of chemicals has been trialed experimentally for control of late $R$. solani infections. In a 3-year field study, single applications of triadimefon and triadamenol at the cotyledon to 4-6 leaf stage, effectively suppressed Rhizoctonia root rot of sugar beets for the entire season (Ruppel and Hecker 1987). Triadimefon was also promising when applied to crowns and bases of plants in field plots artificially infected with $R$. solani (Schneider and Potter 1983). In these experiments, chlorothalonil, PCNB and triphenyltin hydroxide (TPTH) applications also suppressed Rhizoctonia infections. Outstanding control of Rhizoctonia was achieved using crown applications of pencycuron to sugar beet (Schneider and Potter 1983). Glasshouse and field experiments conducted more recently in the Lachlan Valley region in Australia, supported this earlier study, with pencyuron clearly displaying superior efficacy to either tolclofos-methyl or iprodione for control of this disease in beetroot (Tesoriero 1993).

More recently, the new strobulurin chemical azoxystrobin was effective in reducing $R$. solani infections in a number of crops including sugar beet (Kiewnick et al. 2001; Zens et al. 1999) and celery (O'Neill et al. 1999). Crown and root rots were reduced by $50 \%$ over 3 years in field trials treated with azoxystrobin (76-304 g a.i./ha) as in-furrow sprays. Band spray applications of azoxystrobin to plant crowns at the 4-leaf stage were demonstrably better than in-furrow applications at planting (Kiewnick et al. 2001), adding support to the hypothesis that Rhizoctonia crown rot infection is predominantly initiated through deposit of infested soil into plant crowns during cultivation. Stobulurin fungicides are largely protective in their mode of action, with only weak systemic activity. Consequently the superior efficacy of azoxystrobin when applied to plant crowns, the site of infection for Rhizoctonia on beets, compared with application to the furrow, is not surprising. In these same trials, tebuconazole reduced crown and root rots by $90 \%$ over the 3 years when applied at $250 \mathrm{~g}$ a.i./ha as in furrow sprays
(Kiewnick et al. 2001). These chemicals warrant further assessment for control of other beet pathogens.

Host resistance. In the USA, public beetroot breeding programs have been conducted at the University of Wisconsin-Madison and New York State Agricultural Experiment Station, Geneva. Unfortunately, only limited reference to varietal releases from both programs could be found in the literature (Abawi and Ludwig 2001; Goldman 1996; Marx 1986). The inbred lines released from the Wisconsin breeding program have been used in the production of hybrid beet seed throughout the world. A list of releases from this program has been published (Goldman 1996), however, it gives no information on the relative susceptibility of each variety to soilborne pathogens. A principle objective of the Geneva breeding program was to develop breeding material with tolerance or resistance to root rot. Some advanced breeding lines from this program showed evidence of tolerance to Pythium root rot in field evaluations (Marx 1986), however it is unclear whether any of these lines have become commercially available since this information was published.

From 1994 to 1997 several commercial beetroot varieties and promising lines were evaluated for resistance to $R$. solani infections under field conditions in New York State (Abawi and Ludwig 2000). All the beet lines evaluated were susceptible to Rhizoctonia however differences in the level of susceptibility were detected. The variety Red Ace consistently displayed lower disease susceptibility than 4 of the other lines tested (Moneta, Exp 5033, Kestral, Scarlet Supreme). Two additional varieties, Red Cloud and Rocket also developed only a low incidence of disease, however this result was complicated by poor germination in these seed lots (Abawi and Ludwig 2000).

Irrigation management. Wet soils favour the development of root rot epidemics in beets. There has been little consideration in the literature of the possibility of manipulating irrigation for the purpose of disease control in this crop. Piccinni and Rush (2000) found that sugar beets irrigated every 4 weeks had the lowest disease incidence and highest yield when grown in soils infested with Beet necrotic yellow vein virus (BNYVV) and Beet soilborne mosaic virus (BSBMV). In this study, sugar beets irrigated every 2 or 3 weeks had significantly higher levels of disease than those irrigated every 4 or 5 weeks. Similarly, reduced irrigation resulted in significantly lower disease incidence in sugar beet crops grown at sites infested with $A$. cochlioides and $R$. solani in 3 replicated trials (Harveson and Rush 2002).

Positive correlations between levels of Aphanomyces root rot and soil matric potential were also observed in a glasshouse study (Rush and Vaughn 1993). In this instance, seedlings in pots irrigated only at pre-planting were significantly less diseased than those irrigated for emergence after planting.

In reality, manipulation of irrigation as a disease management tool in commercial cropping situations is 
unlikely to be a feasible option, particularly in Australian production areas, where irrigation is frequently a limiting factor in beet production. These studies do however, help to highlight the importance of soil moisture in the development of soilborne disease epidemics in beet.

Host resistance is likely to offer the Australian beetroot industry the most benefit of any post-plant management option available. This opinion is however based on the assumption that suitable sources of resistance can be located and made available to the Australian industry. It would be beneficial to assess beetroot varieties for resistance to beet soilborne diseases in Australian production districts. Post-emergence fungicide applications, particularly for Rhizoctonia control, should also be considered along with host resistance. But if this is to be viable, it will also be important to weigh up the risks of the potential for development of fungicide resistance, as well as the economic implications for growers trying to incorporate post-plant fungicide applications into their production systems.

\section{Conclusions}

The soilborne fungal diseases currently jeopardising the Australian beetroot industry are not unique to Australia. The same diseases have been the focus of much research effort in sugarbeet and beetroot crops in many parts of the world. This review has considered the disease management options utilised elsewhere to identify the options that are likely to be the most useful for management of the diseases in Australian production systems.

For Australian beetroot producers, a soilborne disease management strategy comprising a combination of control tactics is likely to be required for effective disease control since no single control measure has been effective elsewhere.

Control measures include those that reduce disease inoculum potential in the soil, or those that protect the beetroot plant from becoming infected by fungal pathogens. The most prospective strategy seems to be to combine a fungicide seed dressing combination of hymexazol and pencycuron or tolclophos methyl with rotations of gramineous crops and/or biofumigant crops, confining sowing to cooler drier months of low disease risk, and the use of beetroot varieties with resistance to Rhizoctonia. Seed priming also warrants consideration, since it has been shown to increase the rate, uniformity and percentage of germination, as well as reducing pre-emergence damping-off by Pythium spp.

Seed dressings are a cost-effective means of reducing pathogen inoculum and protecting young beets from infection. In comparison to metalaxyl (the registered dressing in Australia) which is only active against Pythium, hymexazol is active against both Pythium and Aphanomyces and pencycuron or tolclophos methyl can be combined with it to give protection against Rhizoctonia. Gramineous and biofumigant crop rotations reduce inoculum potential and improve soil health, and Rhizoctonia-resistant beetroot varieties (if they can be demonstrated to be suited to Australian growing conditions) offer a long-term approach to disease management that can easily be incorporated into existing production systems.

Soil fumigation, biological seed treatments and irrigation manipulation are control tactics that have been explored elsewhere, but are unlikely to be useful in the Australian context. Soil fumigation with metham sodium, although known to be effective for control of soilborne fungal pathogens in beet crops, is probably too expensive for routine use in Australian beetroot unless the benefits of an application span several cropping periods. In comparison, biological seed treatments are not a feasible proposition because of efficacy, application and viability constraints. Additionally, no commercial formulations of endemic biological organisms are available in Australia. Manipulation of irrigation regimens as a disease management strategy is also impractical for Australian beet growers because water availability is typically a limiting factor for beetroot production in Australian beetroot production districts. Fungicides, disease-resistant beetroot varieties, manipulation of sowing times and crop rotations provide the foundation for disease management in Australian beetroot.

\section{References}

Abawi G, Crosier D, Cobb A, Becker R (1986) Root rot of table beets in New York State. New York's Food and Life Sciences Bulletin 115, 1-8.

Abawi G, Ludwig J (2000) Pocket rot disease of beets and its management. In 'New York State vegetable conference and New York berry growers meeting'. 7-10 February, Liverpool, NY. pp. 47-50. (Cornell Cooperative Extension: Ithaca)

Abawi G, Ludwig J (2001) Update on beet diseases and their management. In 'New York State vegetable conference'. 12-15 February, Liverpool, NY. pp. 122-126. (Cornell Cooperative Extension: Ithaca)

Abdalla MY, El-Gizawy AM (2000) Effect of some biological and chemical seed treatments of table beets on incidence of Pythium aphanidermatum damping off in the greenhouse. Alexandria Journal of Agricultural Research 45, 167-177.

Anfinrud M (1999) Tachigaren: phytotoxic effects on sugar beet seed germination and emergence. Seed Technology 21, 49-52.

Asher MJC, Payne PA (1989) The control of seed and soilborne fungi by fungicides in pelleted seed. In 'Proceedings of the 52nd winter congress of the international institute for sugarbeet research'. pp. 179-193. (IISBR: Brussels)

Baker R, Martinson CA (1970) Epidemiology of diseases caused by Rhizoctonia solani. In 'Rhizoctonia solani, biology and pathology'. (Ed. JR Parmeter Jr) pp. 172-188. (University of California Press: Berkeley)

Becker JO, Ohr HD, Grech NM, McGiffen ME Jr, Sims JJ (1998) Evaluation of methyl iodide as a soil fumigant in container and small field plot studies. Pesticide Science 52, 58-62.

Brantner JR, Windels CE (1998) Variability in sensitivity to metalaxyl in vitro, pathogenicity and control of Pythium spp. on sugar beet. Plant Disease 82, 896-899.

Bretzel P von, Stanghellini ME, Kronland WC (1988) Epidemiology of Pythium root rot of mature sugar beets. Plant Disease 72, 707-709.

Byford WJ (1975) Observations on the occurrence of Aphanomyces cochlioides in the agricultural soils in England. Transactions of the British Mycological Society 65, 159-162. 
Byford WJ, Payne PA (1983) Experiments with hymexazol treatment of sugar-beet seed and observations on sugar-beet plants infected at the seedling stage by Aphanomyces cochlioides. In 'Aspects of applied biology. Pests, diseases, weeds and weed beet in sugar beet. No. 2'. pp. 99-101.

Coons GH, Kotila JE, Bockstahler HW (1946) Blackroot of sugar beets and possibilities for its control. Proceedings of the American Society of Sugar Beet Technologists 4, 364-380.

Crosier DC, Cobb AC, Abawi GS (1986) Beet root rot: results of 1985. In 'Proceedings of the NewYork State processing vegetable conference'. New York. p. 78-81. (Cornell Cooperative Extension: Ithaca)

Deems RE, Young HC (1956) Black root of sugar beets as influenced by various cropping sequences and their associated mycofloras. Journal of the American Society of Sugarbeet Technologists 9, 32-43.

Durrant MJ, Payne PA, Prince JWF, Fletcher R (1988). Thiram steep seed treatment to control Phoma betae and improve the establishment of the sugar-beet plant stand. Crop Protection 7, 319-326.

Georgakopoulos DG, Fiddaman P, Leifert C, Malathrakis NE (2002) Biological control of cucumber and sugarbeet damping off caused by Pythium ultimum with bacterial and fungal antagonists. Journal of Applied Microbiology 92, 1078-1086.

Goldman IL (1996) A list of germplasm releases from the University of Wisconsin table beet breeding program, 1964-1992. HortScience 31, 880-881.

Guedes AC, Cantliffe DJ (1980) Germination of lettuce seeds at high temperatures after seed priming. Journal of the American Society of Horticultural Science 105, 777-781.

Hancock JG (1977) Factors affecting soil populations of Pythium ultimum in the San Joaquin Valley of California. Hilgardia $\mathbf{4 5}$ $107-122$

Harman GE, Taylor AG (1988) Improved seedling performance by integration of biological control methods at favourable $\mathrm{pH}$ levels with solid matrix priming. Phytopathology 78, 520-525.

Harveson RM, Rush CM (1994) Evaluation of fumigation and Rhizomania-tolerant cultivars for control of a root disease complex of sugar beets. Plant Disease 78, 1197-1202.

Harveson RM, Rush CM (2002) The influence of irrigation frequency and cultivar blends on the severity of multiple root diseases in sugar beets. Plant Disease 86, 901-908.

Heijbroek W, Huijbregts AWM (1995) Fungicides and insecticides applied to pelleted sugar beet seeds. II. Control of pathogenic fungi in soil. Crop Protection 5, 363-366.

Herr LJ (1987) Populations of Rhizoctonia solani in soil under crops in rotation with sugar beet. Annals of Applied Biology 110, 17-24.

Herr LJ (1991) Relationship of binucleate Rhizoctonia isolates used for biocontrol of Rhizoctonia crown rot of sugar beet to anastomosis systems. Canadian Journal of Microbiology 37, 339-344.

Huijbregts AWM, Gijssel PD, Heijbroek W (1995) Fungicides and insecticides applied to pelleted sugar-beet seeds - I. Dose, distribution, stability and release patterns of active ingredients. Crop Protection 14, 355-362.

Hutton DG, O'Brien RG (1986) Aphanomyces cochlioides Dreschler, a cause of root rot of beetroot in Queensland. Australasian Plant Pathology 15, 64-65.

Hyakumachi M, Ui T (1982) The role of the overwintered plant debris and sclerotia as inoculum in the field occurred with sugarbeet root rot. Annals of the Phytopathological Society of Japan 48, 628-633.

Johnson DJ, Halloin JM (2000) A survey of Pythium seedling disease in Michigan sugarbeet fields. Phytopathology 90, S39.

Johnson DJ, Halloin JM (2001) Metalaxyl resistance in M1 isolates of Pythium spp. and the development of a seedling disease nursery. In 'Proceedings of the 31 st biennial meeting (agriculture) of the American Society of Sugar Beet Technologists'. Vancouver. pp. 156-160. (American Society of Sugarbeet Technologists: Denver)

Khan AA, Peck NH, Samimy C (1980) Seed osmoconditioning: physiological and biochemical changes. Israel Journal of Botany 29, 133-144.

Khan AA, Peck NH, Taylor AJ, Samimy C (1983) Osmoconditioning of beet seeds to improve the emergence and yield in cold. Agronomy Journal 75, 788-794.

Khan AA, Taylor AG (1986) Polyethylene glycol incorporation in table beet seed pellets to improve emergence and yield in wet soil. HortScience 21, 987-989.

Kiewnick S, Jacobsen BJ, Braun-Kiewnick A, Eckhoff J, Bergman J (2001) Integrated control of Rhizoctonia crown and root rot of sugar beet with fungicides and antagonistic bacteria. Plant Disease $\mathbf{8 5}$, $718-722$.

Kirkegaard JA, Wong PTW, Desmarchelier JM (1996) In vitro suppression of fungal root pathogens of cereals by Brassica tissues. Plant Pathology 45, 593-603.

Kuznia R, Windels CE (1993) 'Identification and pathogenicity of Pythium spp. isolated from sugarbeet - 1992 sugarbeet research extension report.' Northwest Experiment Station, University of Minnesota, Crookston.

Lewis JA, Papavizas GC (1971a) Damping-off of sugarbeets caused by Aphanomyces cochlioides as affected by soil amendments and chemicals in the greenhouse. Plant Disease Reporter 55, 440-444.

Lewis JA, Papavizas GC (1971b) Effect of sulphur-containing volatile compounds and vapors from cabbage decomposition on Aphanomyces euteiches. Phytopathology 61, 208-214.

Lewis JA, Papavizas GC (1987a) Reduction of inoculum of Rhizoctonia solani in soil by germlings of Trichoderma hamatum. Soil Biology and Biochemistry 19, 195-201.

Lewis JA, Papavizas GC (1987b) Application of Trichoderma and Gliocladium in alginate pellets for control of Rhizoctonia damping-off. Plant Pathology 36, 438-446.

Marx GA (1986) Breeding for root rot tolerance: progress report. In 'Proceedings of the New York State processing vegetable conference'. New York. p. 73. (Cornell Cooperative Extension: Ithaca)

Matthiessen J (1999) 'How degrading — September 1999.' CSIRO Entomology, No. 1, Wembley.

Matthiessen J (1994) 'Horticulture, biofumigation update September 1994.' CSIRO Entomology, No. 1, Wembley.

Matthiessen J, Kirkegaard J (1996) 'Horticulture, biofumigation update - December 1996.' CSIRO Entomology, No. 5, Wembley.

Maude RB, Vizor AS, Schuring CG (1969) The control of fungal seed-borne diseases by means of a thiram seed soak. Annals of Applied Biology 64, 245-257.

Mexal J, Fisher JT, Osteryoung J, Reid CPP (1975) Oxygen availability in polyethylene glycol solutions and its implications in plant-water relations. Plant Physiology 55, 20-24.

Muehlchen AM, Rand RE, Parke JL (1990) Evaluation of crucifer green manures for controlling Aphanomyces root rot of peas. Plant Disease 74, 651-654.

Mumford DL (1968) Evaluating soil samples for fungus diseases of sugar beet seedlings. Journal of the American Society of Sugarbeet Technologists 15, 255-258.

Nakanishi T, Sisler HD (1983) Mode of action of hymexazol in Pythium aphanidermatum. Journal of Pesticide Science 8, 173-181.

O'Brien RG, Wright D, Skett M (1998) 'Development of a disease indexing package to predict crop losses in peas and beetroot.' Horticulture Research and Development Corporation, Final Project Report, Sydney.

O'Brien RG (1988) 'Beetroot hairy root investigation - experiment report.' Queensland Department of Primary Industries, Indooroopilly, Qld. 
Olaya G, Abawi G (1994a) Characteristics of Rhizoctonia solani and binucleate Rhizoctonia species causing foliar blight and root rot on table beets in New York State. Plant Disease 78, 800-804.

Olaya G, Abawi G (1994b) Influence of inoculum type and moisture on development of Rhizoctonia solani on foliage of table beets. Plant Disease 78, 805-810.

O'Neill TM, Hilton G, Thornton C (1999) Evaluation of fungicides for control of crater spot (Rhizoctonia solani) in protected celery. Tests of Agrochemicals and Cultivars 20, 12-13.

Ohr HD, Sims JJ, Grech NM, Becker JO, McGiffen ME Jr (1996) Methyl iodide, an ozone-safe alternative to methyl bromide as a soil fumigant. Plant Disease 80, 731-735.

Osburn RM, Schroth MN (1988) Effect of osmopriming sugarbeet seed on exudation and subsequent damping off. Phytopathology 9, $1246-1250$

Osburn RM, Schroth MN (1989) Effect of osmopriming sugar beet seed on germination rate and incidence of Pythium ultimum damping off. Plant Disease 73, 21-24.

Osburn RM, Schroth MN, Hancock JG, Hendson M. (1989) Dynamics of sugar beet seed colonization by Pythium ultimum and Pseudomonas species: effects on seed rot and damping-off. Phytopathology 79, 709-716.

Payne PA, Williams GE (1990) Hymexazol treatment of sugar-beet seed to control seedling disease caused by Pythium spp. and Aphanomyces cochlioides. Crop Protection 9, 371-377.

Piccinni G, Rush CM (2000) Determination of optimum irrigation and water use efficiency of sugar beet grown in pathogen-infested soil. Plant Disease 84, 1067-1072.

Raftoyannis Y, Dick M (2002) Effects of inoculum density, plant age and temperature on disease severity caused by pythiaceous fungi on several plants. Phytoparasitica 30, 67-76.

Ramirez-Villapudua J, Munnecke DE (1988) Effect of solar heating and soil amendments of cruciferous residues on Fusarium oxysporum f.sp. conglutinans and other organisms. Phytopathology 78, 289-295.

Roberts PA, Magyarosy AC, Matthews WC, May DM (1988) Effects of metham sodium applied by drip irrigation on root knot nematodes, Pythium ultimum, and Fusarium sp. in soil and on carrot and tomato roots. Plant Disease 72, 213-217.

Ruppel EG, Hecker RJ (1987) Prelayby applications of experimental fungicides for suppressing Rhizoctonia root rot in sugar beet. Plant Disease 71, 694-698.

Ruppel EG, Stanghellini ME, Schweizer EE (1988) Damping off of fodder beet induced by Pythium salpingophorum in Colorado. Plant Disease 72, 175.

Rush CM (1991) Comparison of seed priming techniques with regard to seedling emergence and Pythium damping off. Phytopathology 81, 878-882.

Rush CM (1992) Stand establishment of sugar beet seedlings in pathogen-infested soils as influenced by cultivar and seed-priming technique. Plant Disease 76, 800-805.

Rush CM, Vaughn KM (1993) Effect of irrigation, soil matric potential, and seed germination and damping-off caused by Aphanomyces cochlioides. Phytopathology 83, 202-206.

Rush CM, Winter SR (1990) Influence of previous crops on Rhizoctonia root and crown rot of sugar beet. Plant Disease 74, 421-425.

Schauffle WR, Winner C (1979) Effects of crop rotation on parasitic oomycete damage to feeding roots of sugar beet. In 'Soil borne plant pathogens'. (Eds B Schippers, W Grams) pp. 343-349. (Academic Press: London)

Schneider CL, Potter HS (1983) Efficacy of some fungicides in controlling Rhizoctonia crown rot of sugarbeet. Journal of the American Society of Sugarbeet Technologists 22, 54-59.
Schneider CL, Robertson LS (1975) Occurrence of diseases of sugar beet in a crop rotation experiment in Saginaw County, Michigan in 1969-1970-1971. Plant Disease Reporter 59, 194-197.

Scholten OE, Panella LW, Bock TSM de, Lange W (2001) A greenhouse test for screening sugar beet (Beta vulgaris) for resistance to Rhizoctonia solani. European Journal of Plant Pathology 107, 161-166.

Schuster ML, Harris L (1960) Incidence of Rhizoctonia crown rot of sugarbeet in irrigated crop rotation. Journal of the American Society of Sugarbeet Technologists 11, 128-136.

Stephens PM, Davoren CW, Wicks T (1999) Effect of methyl bromide, metham sodium and the biofumigants Indian mustard and canola on the incidence if soilborne fungal pathogens and growth of grapevine nursery stock. Australasian Plant Pathology 28, 187-196.

Taylor AG, Hadar Y, Norton JM, Khan AA, Harmen GE (1985) Influence of pre-sowing seed treatments of table beets on the susceptibility to damping off. Journal of the American Society of Horticulture 110, 516-519.

Tesoriero L. (1993) 'Management strategies for Rhizoctonia disease of processing beetroot.' Horticultural Research and Development Corporation, Final Project Report, Sydney.

Thrane C, Nielsen MN, Sorensen J, Olsson S (2001) Pseudomonas fluorescens DR-54 reduces sclerotia formation, biomass development, and disease incidence of Rhizoctonia solani causing damping-off in sugar beet. Microbial Ecology 42, 438-445.

Vestburg M (1987) The effect of preceding crops on damping off of sugar beet and some ecological properties of the fungus Pythium Pringsh. Journal of Agricultural Science in Finland 59, 87-100.

Vestburg M, Tahvonen R, Raininko K, Nuormala N (1982) Damping off of sugar beet in Finland I. Causal agents and some factors affecting the disease. Journal of the Scientific Agricultural Society of Finland 54, 225-244.

Walker R, Rossall S, Asher MJC (2002) Colonization of the developing rhizosphere of sugar beet seedlings by potential biocontrol agents applied as seed treatments. Journal of Applied Microbiology 92, 228-237.

Whipps JM, McQuilken MP, Budge SP (1993) Use of fungal antagonists for biocontrol of damping off and Sclerotinia diseases. Pesticide Science 37, 309-313.

Whitney ED, Duffus JE (Eds) (1986) 'Compendium of beet diseases and insects.' (American Phytopathological Society: St Paul, MN)

Wicks TJ, Morgan B, Hall B (1996) Influence of soil fumigation and seed tuber treatment on the control of Rhizoctonia solani on potatoes. Australian Journal of Experimental Agriculture 36, 339-345.

Williams GE, Asher MJC (1996) Selection of rhizobacteria for the control of Pythium ultimum and Aphanomyces cochlioides on sugar-beet seedlings. Crop Protection 15, 479-486.

Wilson CL, Solar JM, Ghaouth A, Fravel DR (1999) Benzaldehyde as a soil fumigant, and an apparatus for rapid fumigant evaluation. HortScience 34, 681-685.

Yamada Y (1986) Monceren (Pencycuron), a new fungicide. Japan Pesticide Information 48, 16-22.

Yuen GY, Scroth MN, Weinhold AR, Hancock JE (1991) Effects of soil fumigation with methyl bromide and chloropicrin on root health and yield of strawberry. Plant Disease 75, 416-420.

Zens J, Dehne HW (1999) Rhizoctonia solani on sugar beet differentiation and control. In 'Proccedings of the 12th international Reinhardsbrunn symposium'. (Eds H Lyr, PE Russell, HW Dehne, HD Sisler) pp. 179-185. (Intercept Ltd, Andover: Freidrichroda, Germany)

Received 5 September 2002, accepted 20 May 2003 